\title{
Faktor-faktor yang Memengaruhi Realisasi Pembiayaan Mikro Syariah dan Dampaknya terhadap Omzet Usaha Nasabah: Studi Kasus KJKS BMT UGT Sidogiri Cabang Koja Jakarta
}

\section{The Factors Affecting the Amount of Islamic Microfinance and Its Impact on Customer's Turnover: Case Study KJKS BMT UGT Sidogiri Branch Koja Jakarta}

\author{
Nadiah Hidayati, Widyastutik \& Ranti Wiliasih \\ Departement of Economics, Bogor Agricultural University
}

\begin{abstract}
Micro-business has a role of the national economy development. However, micro scale entrepreneurs face problems of limited capital. This studyto analyze the factors affecting the amount of the financing provided BMT and their impact on bussiness turnover. This research was conducted in March-April at KJKS BMT UGT Sidogiri branch Koja Jakarta. This research used a purposive sampling technique with a total of 30 respondents. OLS analysis results proved thatbusiness aset, frequency financing, installment period, and dummy businesshave significantlyeffect on the realization of financing. Meanwhile, the factors affecting the customer's turnover are business aset, amount of financing, business profit after financing, time duration of educational, time duration of business, and dummy business.
\end{abstract}

Keywords: bmt, islamic microfinance institutions, micro enterprises, ols

\begin{abstract}
Abstrak. Usaha mikro memiliki peran dalam perkembangan ekonomi nasional. Akan tetapi, pelaku usaha mikro menghadapi permasalahan yaitu keterbatasan modal. Studi ini menganalisis faktor-faktor yang memengaruhi realisasi pembiayaan yang diberikan BMT dan pengaruhnya terhadap omzet usaha nasabah. Penelitian ini dilaksanakan pada bulan Maret-April di KJKS BMT UGT Sidogiri cabang Koja Jakarta. Penelitian ini menggunakan teknik purposive sampling dengan total responden sebanyak 30 orang. Hasil analisis dengan menggunakan metode OLS membuktikan bahwa variabel aset usaha, frekuensi pembiayaan, jangka waktu angsuran, dan dummy usaha berpengaruh signifikan terhadap realisasi pembiayaan. Sedangkan, faktor-faktor yang memengaruhi omzet usaha nasabah adalah aset usaha, jumlah pembiayaan, laba usaha setelah pembiayaan, lama pendidikan, lama usaha, dan dummy usaha.
\end{abstract}

Kata kunci: bmt, lembaga keuangan mikro syariah, ols, usaha mikro 


\section{PENDAHULUAN}

\section{Latar Belakang}

Indonesia merupakan salah satu negara yang mengalami pertumbuhan ekonomi positif ketika krisis ekonomi global dunia pada semester kedua tahun 2008 sebesar 6.1\% (BPS 2009). Pertumbuhan ekonomi nasional tidak terlepas dari peran sektor usaha mikro, kecil, dan menengah (UMKM). Usaha mikro mempunyai peran penting dalam perkembangan ekonomi nasional. Kinerja usaha mikro dalam beberapa tahun terakhir mengalami peningkatan. Hal ini dapat dilihat dari jumlah unit usaha, penyerapan tenaga kerja, dan kontribusinya terhadap Produk Domestik Bruto (PDB) yang meningkat tahun 2008-2012.

Tabel 1 Perkembangan usaha mikro berdasarkan unit usaha, tenaga kerja, dan PDB Atas Harga Konstan 2000 tahun 2008-2012

\begin{tabular}{lccc}
\hline Tahun & $\begin{array}{c}\text { Unit Usaha } \\
\text { (unit) }\end{array}$ & $\begin{array}{c}\text { Tenaga Kerja } \\
\text { (orang) }\end{array}$ & $\begin{array}{c}\text { PDB Atas Harga } \\
\text { Konstan } \\
\text { (milyar rupiah) }\end{array}$ \\
\hline 2008 & 50847771 & 87810366 & 655703.8 \\
2009 & 52176771 & 89960695 & 682259.8 \\
2010 & 53504416 & 91729384 & 719070.2 \\
2011 & 54559969 & 94957797 & 761228.8 \\
2012 & 55856176 & 99859517 & 790825.6 \\
\hline
\end{tabular}

Sumber: Kementrian Koperasi dan Usaha Kecil Menengah, diolah (2013)

Permasalahan utama yang dihadapi sebagian besar usaha mikro adalah keterbatasan modal. Setyobudi (2007) menyatakan bahwa permasalahan klasik dan mendasar yang dihadapi oleh pelaku usaha mikro kecil menengah ialah permasalahan modal. Hal inilah yang menjadi tantangan bagi usaha mikro untuk tetap mampu mempertahankan keberadaannya dan mampu berkembang dengan keterbatasan dan berbagai kendala yang ada.

Adanya ketimpangan akses terhadap modal untuk usaha mikro dari lembaga-lembaga keuangan formal seperti perbankan, menyebabkan pelaku usaha mikro bergantung pada sumber-sumber informal. Bank dan lembaga keuangan menganggap sektor usaha mikro memiliki potensi, tetapi bank terhalang dengan kendala prinsip prudent penyaluran kredit. Pada umumnya, pelaku usaha mikrounbankable karena tidak memiliki aset legal dan memadai untuk dijaminkan pada pihak bank. Hal ini terlihat dari kecilnya proporsi kredit yang disalurkan untuk usaha mikro dibandingkan usaha kecil dan menengah.

Tabel 2 Jumlah kredit usaha mikro kecil menengah bank umum periode Juli-Desember tahun 2013 (milyar)

\begin{tabular}{lllllll}
\hline Skala Usaha & Juli & Agustus & September & Oktober & November & Desember \\
\hline Total & 583859 & 579308 & 589361 & 589229 & 595372 & 608823 \\
Mikro & 112503 & 112249 & 114359 & 115785 & 117186 & 118889 \\
Kecil & 176375 & 176440 & 178786 & 182600 & 182600 & 186382 \\
Menengah & 294981 & 290619 & 296217 & 292615 & 295587 & 303552 \\
\hline
\end{tabular}

Sumber: Bank Indonesia (2014)

Berdirinya Lembaga Keuangan Mikro Syariah (LKMS) seperti BMT yang memberikan pembiayaan kepada usaha mikro dan kecil menjadi solusi bagi pelaku usaha mikro. BMT menjadi lembaga keuangan alternatif yang dapat memberikan solusi pada permasalahan pembiayaan. Posisi BMT sangat strategis sebagai lembaga yang memberikan layanan bagi usaha mikro dan kecil yang menginginkan jasa layanan syariah. Dengan demikian, keberadaan BMT memiliki dua fungsi utama, yaitu; melakukan kegiatan pengembangan 
usaha-usaha produktif dan investasi dalam meningkatkan kualitas ekonomi pengusaha mikro dan kecil terutama dengan mendorong kegiatan menabung dan menunjang pembiayaan kegiatan ekonominya serta menerima titipan dana zakat, infak dan sedekah serta mengoptimalkan distribusinya sesuai dengan peraturan dan amanahnya (al Arif 2011).

Pusat Inkubasi Usaha Kecil (PINBUK) dalam Septiana [10], salah satu organisasi yang mendirikan banyak BMT mencatat sampai dengan akhir tahun 2010 terdapat sekitar 3 900 BMT yang beroperasi di Indonesia. Total aset yang dikelola mencapai nilai Rp 5 triliun, nasabah yang dilayani sekitar 3.5 juta orang, dan jumlah pekerja yang mengelola sekitar 20 ribu orang. Pertumbuhan kelembagaan dan jumlah nasabah membawa perkembangan yang pesat pula dalam kinerja keuangannya.

Dengan pangsa pasar yang potensial, lembaga keuangan mikro syariah seperti BMT berdiri untuk memberikan solusi permodalan kepada usaha mikro. Koperasi Jasa Keuangan Syariah (KJKS) BMT UGT Sidogiri berdiri sejak 6 Juni 2000 di Surabaya. Saat ini KJKS BMT UGT Sidogiri telah berusia 13 tahun dan sudah memiliki 230 unit layanan Baitul Maal wat Tamwil (BMT) dan 1 unit layanan transfer. Dalam setiap tahun, KJKS BMT UGT Sidogiri membuka beberapa unit pelayanan anggota di kabupaten/kota yang dinilai potensial. Terdapat 3 cabang KJKS BMT UGT Sidogiri di Jakarta, antara lain berada di Kecamatan Koja, Cakung, dan Warakas. KJKS BMT UGT Sidogiri cabang Koja Jakarta telah berdiri sejak tahun 2006 dengan total aset awal sebesar 150 juta rupiah dan jumlah pekerja sebanyak 4 orang.

\section{Perumusan Masalah}

Pembiayaan mikro syariah memiliki peranan penting bagi para pengusaha mikro. Dengan prinsip syariah dimana BMT tidak memberlakukan sistem bunga, BMT dinilai memberikan kemudahan akses terhadap para pengusaha. Hal ini juga sejalan oleh Mahliza [7] yang menjelaskan bahwa pembiayaan syariah menjadi alternatif solusi bagi para pengusaha yang memiliki masalah dalam permodalan.

Salah satu lembaga keuangan mikro syariah yang memberikan solusi altrnatif dalam masalah permodalan usaha mikro ialah Koperasi Jasa Keuangan Syariah (KJKS) BMT UGT Sidogiri. KJKS BMT UGT Sidogiri cabang Koja Jakarta telah berdiri sejak bulan April 2006 dan terletak di Kecamatan Koja, Jakarta Utara merupakan salah satu BMT yang berperan dalam penyaluran dana kepada para pelaku usaha mikro. Setelah eksis selama delapan tahun, KJKS BMT UGT Sidogiri cabang Koja Jakarta telah menyalurkan dana dengan berbagai produk pembiayaan yang dijelaskan dalam Tabel 3.

Tabel 3 Jumlah pembiayaan yang diberikan KJKS BMT UGT Sidogiri cabang Koja Jakarta hingga April 2014

\begin{tabular}{lr}
\hline Jenis Pembiayaan & Jumlah (Rp) \\
\hline Mudharabah (bagi hasil) & 297503500.00 \\
Musyarakah (penyertaan) & 93843344.65 \\
Murabahah (jual beli) & 42699667.99 \\
Bai'bitsamanilajil (jual beli) & 721905951.19 \\
Rahn (gadai syariah) & 22700000.00 \\
\hline
\end{tabular}

Sumber: KJKS BMT UGT Sidogiri cabang Koja Jakarta (2014)

Berdasarkan data performance pembiayaan bulan April 2014, total nasabah aktif pembiayaan sebanyak 121 orang, baik pembiayaan produktif maupun konsumtif. Mayoritas nasabah bergerak di sektor perdagangan dan industri pengolahan makanan serta kerajinan tangan. Sampai saat ini, jumlah realisasi dan nasabah pembiayaan di 
KJKS BMT UGT Sidogiri cabang Koja Jakarta masih belum mencapai target. Target realisasi pembiayaan yang ditetapkan untuk tahun 2013 sebesar Rp 3 triliun, sedangkan jumlah yang direalisasikan sebesar Rp $1 \quad 831572 \quad 269.53$ sehingga persentase pencapaiannya hanya $61.05 \%$ dari target.

Realisasi pembiayaan juga dipengaruhi oleh unsur kehati-hatian yang dianut oleh KJKS BMT UGT Sidogiri cabang Koja Jakarta. Unsur kehati-hatian tetap menjadi prioritas dalam penyaluran dana karena penyaluran dana berkaitan dengan pengembalian. Sebagai implikasinya, tidak semua pelaku usaha mikro mendapatkan pembiayaan dari BMT.

Plafon maksimal pembiayaan pada pada KJKS BMT UGT Sidogiri cabang Koja Jakarta sebesar Rp 35000 000. Dengan plafon sebesar ini, pengusaha mikro diharapkan dapat mengembangkan usahanya, sehingga dapat meningkatkan permintaan realisasi pembiayaan. Untuk dapat mencapai target realisasi pembiayaan tersebut, perlu dilakukan analisis faktor-faktor yang memengaruhi realisasi pembiayaan mikro syariah yang diberikan BMT dan dampaknya terhadap omzet usaha nasabah sehingga pengusaha mikro yang belum mendapatkan pembiayaan bisa memenuhi kriteria BMT dan pengusaha mikro yang sudah menjadi nasabah pembiayaan dapat meningkatkan realisasi pembiayaannya.Berdasarkan penjelasan diatas, permasalahan yang akan dijawab dalam penelitian ini adalah:

1. Faktor-faktor apa saja yang memengaruhi realisasi pembiayaan yang diberikan oleh KJKS BMT UGT Sidogiri cabang Koja Jakarta?

2. Bagaimana pengaruh pembiayaan yang diberikan terhadap omset usaha nasabah?

\section{Tujuan Penelitian}

Berdasarkan uraian latar belakang dan permasalahan diatas, maka tujuan penelitian ini adalah sebagai berikut:

1. Menjelaskan faktor-faktor yang memengaruhi realisasi pembiayaan yang diberikan oleh KJKS BMT UGT Sidogiri cabang Koja Jakarta.

2. Menjelaskan pengaruh pembiayaan yang diberikan terhadap omset usaha nasabah. 


\section{TINJAUAN PUSTAKA}

\section{The Backward-Bending Supply of Credit}

Baitul Maal wat Tamwil (BMT) merupakan lembaga keuangan semi formal dengan prinsip syariah. Sebagai lembaga keuangan, BMT menerapkan unsur kehati-hatian dalam proses penyaluran dana. Hal ini bertujuan untuk menjaga keberlangsungan keberadaannya.

Teori Backward-Bending Supply of Credit dijelaskan oleh Freixas and Rochet (2008) bahwa pembatasan kredit akan terjadi karena adanya asimetri informasi. Lembaga keuangan umumnya bank menerapkan sistem ini ketika peminjam homogen. Sebuah lembaga keuangan berhak menjatah kredit bagi peminjam yang tidak sesuai dengan kriteria lembaga keuangan tersebut.

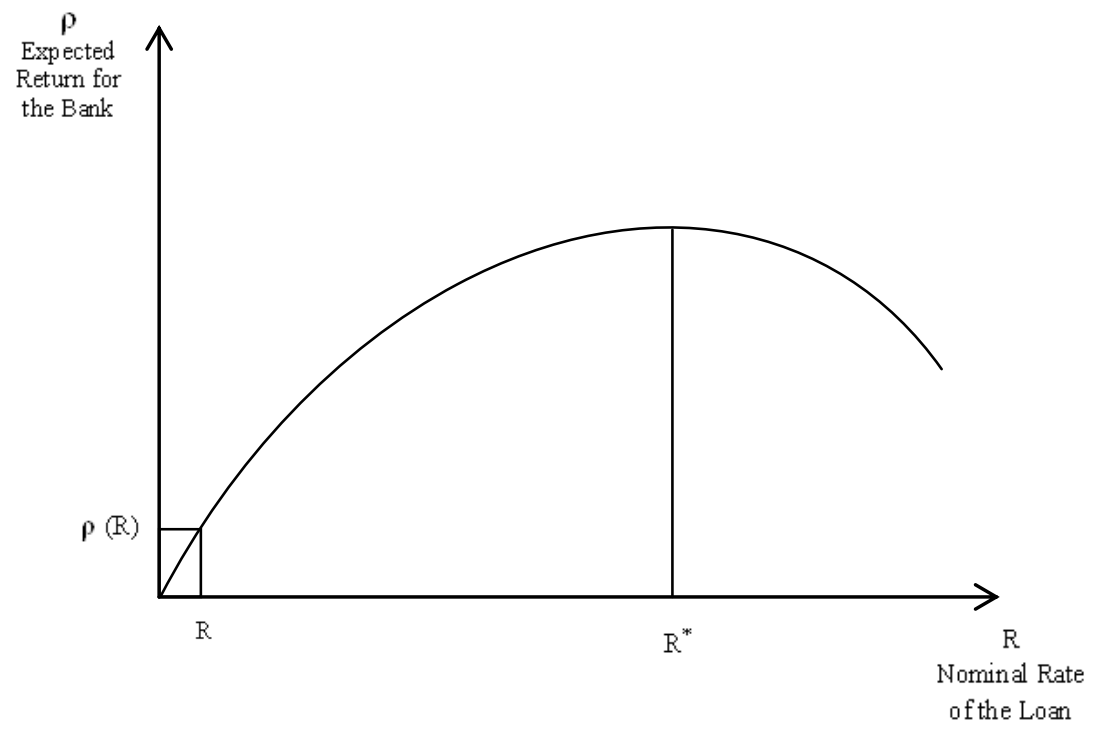

Gambar 1 Teori Backward-Bending supply of credit

Berdasarkan Gambar 1, kredit yang diinginkan peminjam (borrower) tidak sepenuhnya diberikan, ketika pemohon kredit tinggi, sebuah lembaga keuangan cenderung memeriksa dan mengeksplorasi konsekuensi yang akan terjadi pada peminjam tersebut. Kredit yang diterima sampai dengan suku bunga $\mathrm{R}^{*}$, setelah itu akan terjadi zero profit dan lembaga keuangan tersebut akan melakukan penjatahan kredit bagi peminjam. Pihak pemberi pinjaman (lender) akan melakukan hal tersebut untuk mengurangi terjadinya gagal bayar.

\section{Asimetri Informasi}

Salah satu kendala yang akan muncul antara agen dan pelaku utama adalah adanya asimetri informasi (information asymmetry). Informasi yang tidak simetris merujuk pada situasi dimana dalam sebuah transaksi salah satu pihak memiliki lebih banyak informasi mengenai transaksi tersebut daripada pihak lain. Arsyad (2008) menyatakan bila bank dianggap sebagai pelaku utama dan peminjam sebagai agen, tingkat bunga yang dikenakan kepada pinjaman memengaruhi tingkah laku peminjam. Bank dapat memilih untuk menetapkan tingkat bunga yang tidak melebihi pasar kredit jika pilihan tersebut dibuat sebagai salah satu cara untuk mempengaruhi tingkah laku peminjam yang tidak dapat diawasi dan penggunaan pinjaman. 
Menurut Scott (2000), terdapat dua macam asimetri informasi yaitu:

1. Adverse selection, yaitu bahwa para manajer serta orang-orang dalam lainnya biasanya mengetahui lebih banyak tentang keadaan dan prospek perusahaan dibandingkan pihak luar.

2. Moral hazard, yaitu kegiatan yang dilakukan oleh seorang manajer tidak seluruhnya diketahui oleh pemegang saham maupun pemberi pinjaman. Sehingga, manajer dapat melakukan tindakan diluar pengetahuan pemegang saham yang melanggar kontrak dan sebenarnya secara etika atau norma mungkin tidak layak dilakukan.

\section{Pembiayaan Syariah}

Pembiayaan atau financing ialah pendanaan yang diberikan oleh suatu pihak kepada pihak lain untuk mendukung investasi yang telah direncanakan, baik dilakukan sendiri maupun lembaga. Dengan kata lain, pembiayaan adalah pendanaan yang dikeluarkan untuk mendukung investasi yang telah direncanakan (Al-Arif 2011).

\section{Faktor-faktor yang Memengaruhi Pembiayaan}

Sebagai lembaga keuangan non-bank, BMT mempunyai pertimbangan dalam penyaluran pembiayaan kepada nasabah. Faktor-faktor yang memengaruhi besarnya pembiayaan yang diberikan kepada nasabah adalah pendapatan bersih usaha, frekuensi pinjaman, besar tunggakan, dan jangka waktu angsuran (Arsyad 2008).

\section{Prinsip-prinsip Pembiayaan}

Dalam kegiatan pembiayaan, prinsip-prinsip kredit diterapkan dalam penyaluran dana yang dikenal dengan 5C, yaitu (Kasmir 2004):

1. Character, yaitu sifat atau watak calon debitur. Hal ini bertujuan memberikan keyakinan kepada pihak perbankan bahwa sifat dari orang-orang yang akan diberikan kredit dapat dipercaya.

2. Capacity, yaitu kemampuan calon debitur dalam membayar kredit yang dihubungkan dengan kemampuan calon debitur tersebut dalam mengelola bisnis serta kemampuannya mengelola keuntungan.

3. Capital, yaitu sumber-sumber pembiayaan yang dimiliki calon debitur dalam usaha yang dilakukannya.

4. Collateral, yaitu jaminan yang diberikan calon debitur yang bersifat fisik maupun non fisik. Jaminan yang diberikan dianjurkan melebihi jumlah kredit yang diberikan.

5. Condition, yaitu penilaian kredit yang mempertimbangkan kondisi sekarang dan masa yang akan datang.

\section{METODE PENELITIAN}

\section{Jenis dan Sumber Data}

Penelitian ini menggunakan data primer yang diperoleh melalui penyebaran kuesioner dan wawancara dengan responden yang merupakan nasabah pembiayaan serta hasil wawancara dengan pihak pengelola KJKS BMT UGT Sidogiri cabang Jakarta di Kecamatan Koja, Jakarta Utara. 


\section{Lokasi dan Waktu Penelitian}

Penelitian ini dilakukan di KJKS BMT UGT Sidogiri cabang Jakarta di Kecamatan Koja, Jakarta Utara. Pemilihan BMT tersebut dilakukan secara purposive (sengaja) dengan pertimbangan bahwa KJKS BMT UGT Sidogiri merupakan KJKS terbesar di Indonesia (Kementriaan Koperasi dan UKM tahun 2012) dan cabangnya yang berada di Kecamatan Koja merupakan cabang pertama di Jakarta dengan total aset terbesar diantara cabang lainnya dan berdiri sejak tahun 2006. Penelitian ini dilaksanakan pada bulan Maret hingga April 2014.

\section{Metode Pengumpulan Data}

Pengumpulan data dalam penelitian ini menggunakan metode wawancara dengan kuesioner sebagai alat bantu dan penelusuran literatur. Dalam hal ini, informasi diperoleh langsung dari responden dan pihak KJKS BMT UGT Sidogiri cabang Koja Jakarta dengan cara tatap muka. Berdasarkan data performence bulan Januari hingga April 2014, nasabah aktif pembiayaan KJKS BMT UGT Sidogiri cabang Koja Jakarta berjumlah 121 orang. Pengambilan sampel dilakukan dengan teknik pengambilan sampel non probabilitas (non acak) yaitu menggunakan teknik purposive sampling. Jumlah responden yang dipilih sebanyak 30 yang mendapatkan pembiayaan dari bulan September 2013 hingga April 2014. Hal ini sejalan oleh Gay et al (2006) yang menyatakan bahwa untuk studi korelasi, setidaknya dibutuhkan 30 responden yang diperlukan untuk menetapkan ada atau tidaknya suatu hubungan.

\section{Metode Pengolahan Analisis Data}

Metode analisis data yang digunakan pada penelitian ini ialah metode kualitatif dan kuantitatif. Analisis data kualitatif dilakukan dengan cara mengumpulkan fakta-fakta yang terjadi dilapangan dari hasil wawancara dengan pelaku usaha mikro dan menggambarkan gambaran umum KJKS BMT UGT Sidogiri cabang Koja Jakarta serta karakteristik responden yang didukung penyajian data dalam bentuk tabulasi.Analisis kuantitatif dilakukan dengan menampilkan hasil pengolahan data dalam bentuk tabel. Penelitian ini menggunakansoftware E-views 6 dengan metode Ordinary Least Square (OLS) untuk melihat faktor-faktor yang memengaruhi realisasi pembiayaan mikro syariah dan pengaruhnya terhadap omset usaha nasabah. Selang kepercayaan dalam penelitian ini ialah $(\alpha=10 \%)$.

\section{Spesifikasi Model}

Model pertama merupakan model statistik untuk melihat faktor-faktor apa saja yang memengaruhi realisasi pembiayaan mikro syariah dari BMT. Berikut ini merupakan model terbaik dengan variabel dependen yaitu jumlah pembiayaan yang direalisasikan dan variabel-variabel independen antara lain: aset usaha, frekuensi pembiayaan, jangka waktu angsuran, laba usaha sebelum pembiayaan dan dummy usaha. Variabel-variabel independen penduga yang merujuk pada penelitian sebelumnya antara lain: umur, dummy agunan, lama pendidikan, lama usaha, lama menjadi nasabah, dan tabungan.

$Y=\beta_{0}+\beta_{1} X_{1}+\beta_{2} X_{2}+\beta_{3} X_{3}+\beta_{4} X_{4}+\beta_{5} D_{1}+e_{i}$

Keterangan :

$\mathrm{Y}=$ = Jumlah pembiayaan yang direalisasikan (rupiah)

$\beta_{0} \quad=$ Intersep 


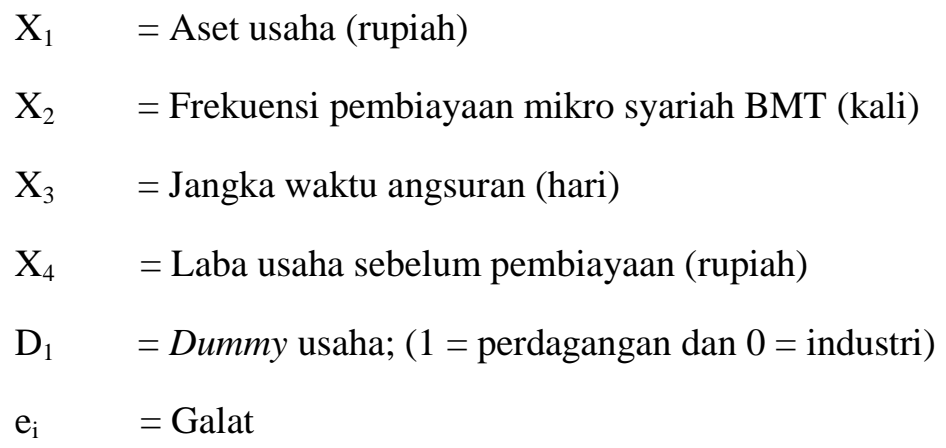

Persamaaan transformasi logaritma natural untuk model persamaan 1 ialah

$\mathrm{LnY}=\beta_{0}+\beta_{1} \operatorname{LnX}_{1}+\beta_{2} \operatorname{LnX}_{2}+\beta_{3} \operatorname{LnX}_{3}+\beta_{4} \operatorname{LnX}_{4}+\beta_{5} \mathrm{D}_{1}+\mathrm{e}_{\mathrm{i}}$

Keterangan :

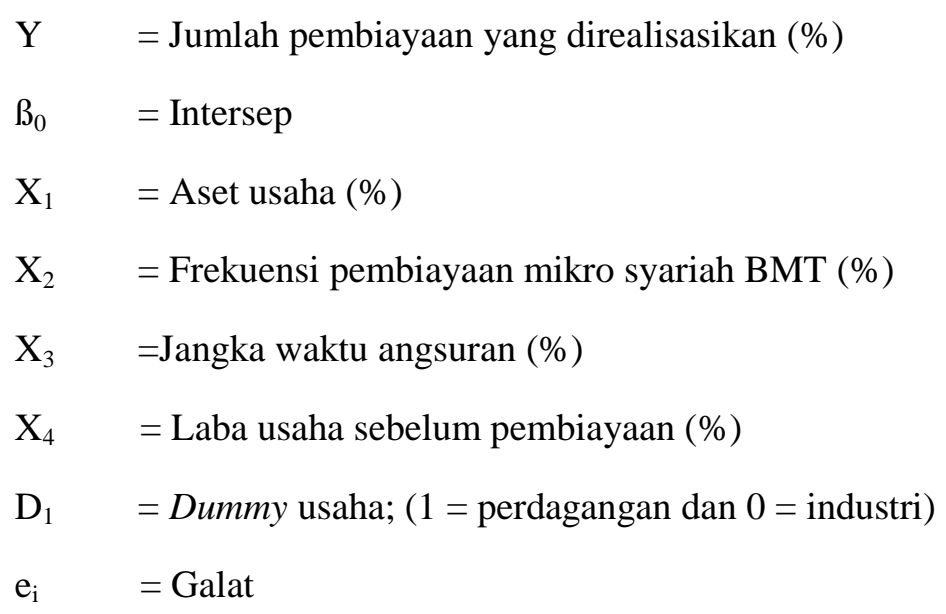

Model kedua merupakan model statistik untuk melihat faktor-faktor apa saja yang memengaruhi omset usaha nasabah setelah pembiayaan. Berikut ini merupakan model terbaik dengan variabel dependen yaitu omset usaha setelah pembiayaan dan variabelvariabel independen antara lain: aset usaha, jumlah pembiayaan mikro syariah BMT, lama pendidikan, laba usaha setelah menerima pembiayaan, lama usaha, dan dummy usaha. Variabel-variabel independen penduga yang merujuk pada penelitian sebelumnya antara lain: umur, modal awal, frekuensi pembiayaan, dan jangka waktu angsuran.

$\mathrm{Y}=\beta_{0}+\beta_{1} \mathrm{X}_{1}+\beta_{2} \mathrm{X}_{2}+\beta_{3} \mathrm{X}_{3}+\beta_{4} \mathrm{X}_{4}+\beta_{5} \mathrm{X}_{5}+\beta_{6} \mathrm{D}_{1}+\mathrm{e}_{\mathrm{i}}$

Keterangan :

$\mathrm{Y} \quad=$ Omset usaha (rupiah)

$\beta_{0} \quad=$ Intersep

$\mathrm{X}_{1}{ }^{`} \quad=$ Aset usaha (rupiah)

$\mathrm{X}_{2} \quad=$ Jumlah pembiayaan mikro syariah BMT (rupiah)

$\mathrm{X}_{3} \quad=$ Lama pendidikan (tahun) 


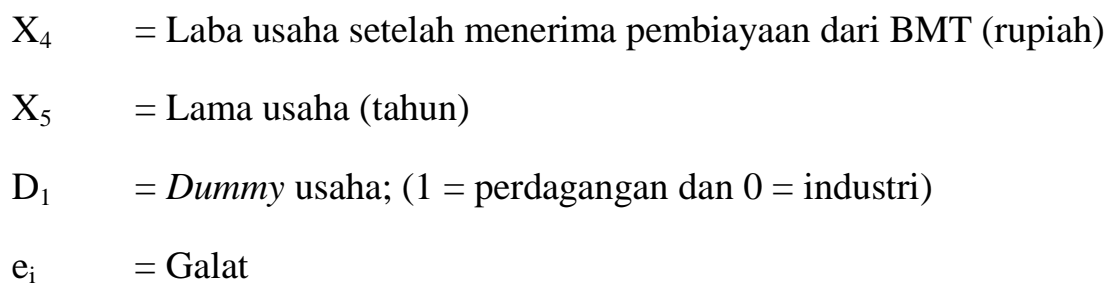

Persamaan transformasi logaritma natural untuk model persamaan 3 ialah

$\mathrm{LnY}=\beta_{0}+\beta_{1} \operatorname{LnX}_{1}+\beta_{2} \operatorname{LnX}_{2}+\beta_{3} \operatorname{LnX}{ }_{3}+\beta_{4} \operatorname{LnX}_{4}+\beta_{5} \operatorname{LnX}{ }_{5}+\beta_{6} \mathrm{D}_{1}+\mathrm{e}_{\mathrm{i}}$

Keterangan :

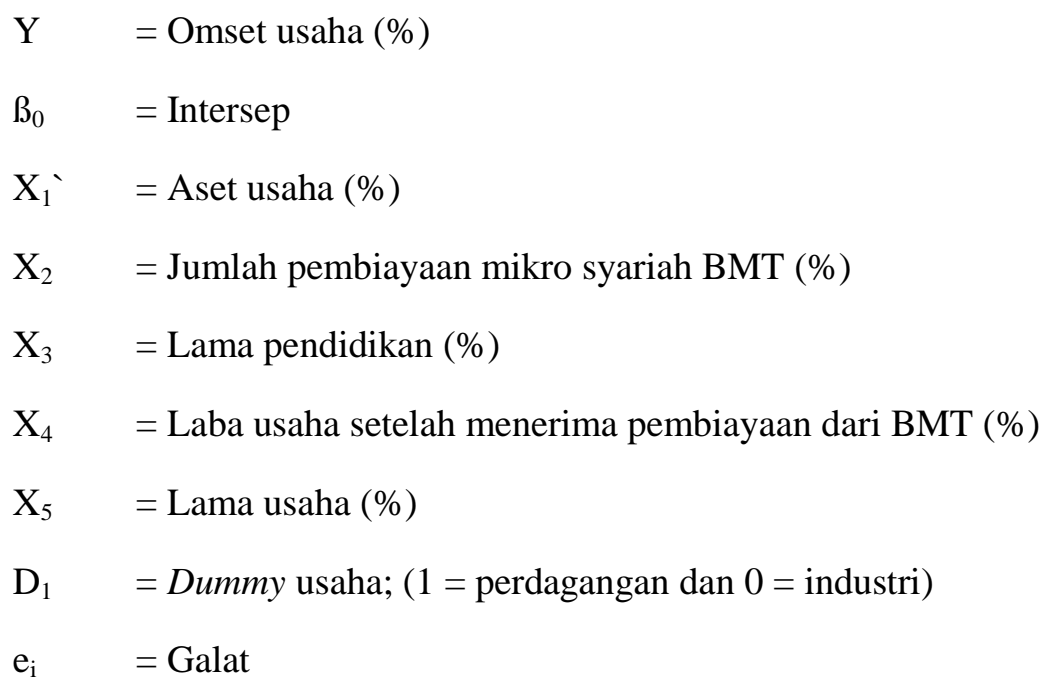

\section{HASIL DAN PEMBAHASAN}

\section{Karakteristik Responden}

\section{Usia Responden}

Usia menjadi sesuatu yang penting karena berkaitan dengan keberanian nasabah dalam mengambil keputusan secara rasional dalam menjalankan usahanya. Hal ini karena peningkatan usia pada ummnya akan mempengaruhi kemampuan berpikir seseorang. Semakin meningkatnya usia, nasabah dianggap telah memiliki pengalaman yang lebih banyak dari sebelumnya dalam menjalankan usaha.

Usia responden dalam penelitian ini antara 21-70 tahun. Berdasarkan Tabel 4 diketahui bahwa proporsi responden sebesar 53.33\% atau sebanyak 16 orang berada pada usia 25 40 tahun. Proporsi responden sebesar 36.67\% atau sebanyak 11 orang berada usia 41-55 tahun. Hal ini menunjukkan bahwa pelaku usaha mikro mayoritas berada dalam usia produktif. Selanjutnya, proporsi responden sebesar $6.67 \%$ atau sebanyak 2 orang berada pada usia 56-65 tahun dan proporsi 3.33\% atau sebanyak 1 orang berada pada usia 15-24 tahun.

Tabel 4 Jumlah dan proporsi responden berdasarkan usia 


\begin{tabular}{lll}
\hline Usia (tahun) & Jumlah Responden (orang) & Proporsi (\%) \\
\hline $15-24$ & 1 & 3.33 \\
$25-40$ & 16 & 53.33 \\
$41-55$ & 11 & 36.67 \\
$56-65$ & 2 & 6.67 \\
\hline Total & 30 & 100 \\
\hline Sul
\end{tabular}

Sumber: Data primer, diolah (2014)

\section{Jenis Kelamin}

Jenis kelamin dapat mendeskripsikan posisi nasabah dalam keluarganya dan dalam usaha yang dijalankannya. Hasil penelitian menunjukan bahwa proporsi responden pria sebesar $40 \%$ atau sebanyak 12 orang, sedangkan proporsi responden wanita yaitu $60 \%$ atau sebanyak 18 orang.

Tabel 5 Jumlah dan proporsi responden berdasarkan jenis kelamin

\begin{tabular}{lll}
\hline Jenis Kelamin & Jumlah Responden (orang) & Proporsi (\%) \\
\hline Pria & 12 & 40.00 \\
Wanita & 18 & 60.00 \\
\hline Total & 30 & 100 \\
\hline
\end{tabular}

Sumber: Data primer, diolah (2014)

\section{Tingkat Pendidikan Akhir}

Hasil penelitian menunjukkan bahwa responden dengan tingkat pendidikan terakhir SMP dan SMA mempunyai proporsi terbesar yaitu masing-masing sebanyak 10 orang (33.33\%). Proporsi terbesar berikutnya yaitu responden dengan tingkat pendidikan terakhir SD sebanyak 9 orang (30\%). Terdapat juga responden dengan tingkat pendidikan tidak tamat SD sebanyak 1 orang (3.33\%). Dari hasil observasi terlihat tidak ada responden dengan tingkat pendidikan lebih dari SMA (Tabel 6).

Tabel 6 Jumlah dan proporsi responden berdasarkan tingkat pendidikan akhir

\begin{tabular}{lll}
\hline Pendidikan & Jumlah Responden (orang) & Proporsi (\%) \\
\hline Tidak tamat SD & 1 & 3.33 \\
SD & 9 & 30.00 \\
SMP & 10 & 33.33 \\
SMA & 10 & 33.33 \\
\hline Total & 30 & 100
\end{tabular}

Sumber: Data primer, diolah (2014)

\section{Jenis Usaha}

Hasil penelitian menunjukkan bahwa responden pembiayaan mayoritas memiliki usaha di bidang perdagangan (Tabel 7). Proporsi responden yang memiliki jenis usaha perdagangan sebanyak 25 orang (83.33\%), seperti pedagang sayuran, komestik, blender, bensin eceran dan sebagainya. Sisanya sebanyak 5 orang $(16.67 \%)$ memiliki usaha di bidang industri, baik industri pengolahan makanan maupun kerajinan.

Tabel 7 Jumlah dan proporsi responden berdasarkan jenis usaha

\begin{tabular}{lll}
\hline Jenis Usaha & Jumlah Responden (orang) & Proporsi (\%) \\
\hline Dagang & 25 & 83.33 \\
Industri & 5 & 16.67 \\
\hline Total & 30 & 100 \\
\hline
\end{tabular}

Sumber: Data primer, diolah (2014) 


\section{Lama Usaha}

Lama usaha usaha responden berkisar dari 2-37 tahun. Proporsi terbesar dimiliki oleh nasabah responden yang lama usahanya 1-5 tahun yaitu sebanyak 13 orang (43.33\%), selanjutnya nasabah dengan lama usaha 6-15 tahun sebanyak 10 orang (33.33\%). Hal ini menunjukkan bahwa para pelaku usaha mikro mayoritas masih merintis usaha dengan lama usaha masih dibawah lima tahun (Tabel 8).

Tabel 8 Jumlah dan proporsi responden berdasarkan lama usaha

\begin{tabular}{lll}
\hline Lama Usaha (tahun) & Jumlah Responden (orang) & Proporsi (\%) \\
\hline$\leq 5$ & 13 & 43.33 \\
$6-15$ & 10 & 33.33 \\
$>15$ & 7 & 23.33 \\
\hline Total & 30 & 100 \\
\hline
\end{tabular}

Sumber: Data primer, diolah (2014)

\section{Agunan}

Agunan merupakan jaminan yang disertakan nasabah ketika melakukan pinjaman pembiayaan. Ditinjau dari sebaran responden berdasarkan ada tidaknya agunan (Tabel 9) diketahui bahwa responden yang menyertakan agunan atau jaminan sebanyak 11 orang (36.67\%), sedangkan sisanya yaitu sebanyak 19 orang (63.33\%) tidak menyertakan agunan dalam pembiayaannya. Ketentuan KJKS BMT UGT Sidogiri cabang Koja Jakarta mewajibkan penyerahan jaminan untuk pembiayaan diatas tiga juta rupiah. Sebagian besar agunan yang diserahkan oleh nasabah ialah BPKB motor, emas, dan sertifikat usaha dari pengelola pasar. Konsekuensi dari tidak menyerahkan agunan kepada pihak BMT ialah nasabah wajib menabung. Hal ini merupakan antisipasi dari pihak BMT terhadap kredit macet. Asas kepercayaan juga diterapkan oleh pihak BMT terhadap nasabah pembiayaannya.

Tabel 9 Jumlah dan proporsi responden berdasarkan agunan

\begin{tabular}{lll}
\hline Agunan & Jumlah Responden (orang) & Proporsi (\%) \\
\hline Ada & 11 & 36.67 \\
Tidak ada & 19 & 63.33 \\
\hline Total & 30 & 100 \\
\hline
\end{tabular}

Sumber: Data primer, diolah (2014)

\section{Legalitas Usaha}

Legalitas usaha terdiri dari Nomor Pokok Wajib Pajak (NPWP), Surat Izin Usaha Perdagangan (SIUP), Tanda Daftar Perusahaan (TDP), Tanda Daftar Industri (TDI), sertifikat pasar, dan surat izin usaha dari RT setempat. Dalam penelitian ini mayoritas responden tidak memiliki legalitas usaha yaitu sebanyak 23 orang (76.67\%), sedangkan sebanyak 7 orang (23.33\%) memiliki legalitas usaha antara lain berupaNPWP, sertifikat yang dikeluarkan oleh pihak pengelola pasar, dan surat izin usaha dari RT setempat (Tabel 10). Hal ini menunjukkan bahwa para pelaku usaha mikro mayoritas tidak memiliki legalitas usaha.

Tabel 10Jumlah dan proporsi responden berdasarkan legalitas usaha

\begin{tabular}{lll}
\hline Legalitas Usaha & Jumlah Responden (orang) & Proporsi (\%) \\
\hline Ada & 7 & 23.33 \\
Tidak ada & 23 & 76.67 \\
\hline Total & 30 & 100 \\
\hline
\end{tabular}

Sumber: Data primer,diolah (2014) 


\section{Modal Usaha}

Pada Tabel 11 menunjukkan modal para pelaku usaha mikro. Modal awal responden mayoritas berada pada interval 0-1 juta rupiah, yaitu sebesar $66.67 \%$ dengan rincian 20 responden.Hal ini menunjukkan bahwa sebagian besar usaha mikro memulai usahanya dengan modal yang cukup rendah. Sedangkan, modal saat ini responden mayoritas berada pada interval $>5$ juta rupiah, yaitu sebesar $40 \%$ dengan rincian 12 responden.

Tabel 11 Jumlah dan proporsi responden berdasarkan modal usaha

\begin{tabular}{|c|c|c|c|c|}
\hline \multirow[b]{2}{*}{ Modal (Rp) } & \multicolumn{2}{|c|}{ Awal } & \multicolumn{2}{|c|}{ Saat ini } \\
\hline & Frekuensi & Proporsi $(\%)$ & Frekuensi & Proporsi(\%) \\
\hline $0-1.000 .000$ & 20 & 66.67 & 8 & 26.67 \\
\hline $\begin{array}{l}> \\
5.000 .000\end{array}$ & 6 & 20.00 & 10 & 33.33 \\
\hline$>5.000 .0000$ & 4 & 13.33 & 12 & 40.00 \\
\hline Total & 30 & 100 & 30 & 100 \\
\hline
\end{tabular}

Sumber: Data primer,diolah (2014)

\section{Akses Pinjaman pada Lembaga Keuangan}

Akses pinjaman rumah tangga responden terhadap lembaga keuangan dapat dilihat pada Tabel 12. Nilai rata-rata pinjaman dari lembaga keuangan formal lebih besar dibandingkan pinjaman dari semi formal. Akan tetapi, responden yang mempunyai akses pinjaman pada lembaga keuangan formal hanya sebesar $10 \%$. Terdapat beberapa hal yang memengaruhi akses responden terhadap lembaga keuangan formal. Mayoritas responden tidak ingin mengambil resiko untuk mengambil kredit pada bank dengan proporsi sebesar $30.43 \%$. Responden tidak berani mengambil resiko karena factor umur yang sudah tua, antisipasi akan kredit macet/gagal bayar, dan tidak ingin terbelit hutang. Alasan lainnya yaitu karena persyaratan dan prosedur pinjaman di BMT lebih mudah (21.73\%), tidak memiliki agunan/jaminan (17.39\%), tidak membutuhkan modal (13.04\%), tidak sesuai syariah (4.34\%), dan alasan lainnya sebesar $4.34 \%$.

Lembaga keuangan formal yang dituju oleh responden adalah BRI. Alasan pemilihan pinjaman pada BRI ialah karena lokasi bank dekat dan berlokasi sama dengan tempat usaha responden sehingga mudah melakukan transaksi saat berdagang. Selain lembaga keuangan formal, responden juga mempunyai akses pada lembaga keuangan semi formal selain BMT. Lembaga keuangan semi formal konvensional yaitu koperasi pasar, sedangkan lembaga keuangan semi formal syariah yaitu lembaga keuangan dana cepat syariah.

Tabel 12 Akses pinjaman pada lembaga keuangan

\begin{tabular}{|c|c|c|}
\hline \multirow{2}{*}{ Akses Pinjaman } & \multicolumn{2}{|c|}{ Responden } \\
\hline & Nilai Rata-rata $(\mathrm{Rp})$ & Partisipasi \\
\hline \multicolumn{3}{|l|}{ Formal } \\
\hline Bank & 15333333 & $\mathrm{n}=3(10 \%)$ \\
\hline \multicolumn{3}{|l|}{ Semi Formal } \\
\hline BMT & 4133333 & $\mathrm{n}=30(100 \%)$ \\
\hline Konvensional & 3750000 & $\mathrm{n}=3(10 \%)$ \\
\hline Syariah (NonBMT) & 3000000 & $\mathrm{n}=1(3.33 \%)$ \\
\hline
\end{tabular}

Sumber: Data primer, diolah (2014) 


\title{
Pengajuan dan Pencairan Pembiayaan
}

Proses pengajuan dan pencairan pembiayaan di KJKS BMT UGT Sidogiri cabang Koja Jakarta tergolong mudah. Gambar 1 menunjukkan jumlah responden saat pengajuan dan pencairan pembiayaan dimana 13 responden datang ke BMT saat proses pengajuan, sedangkan sisanya 17 responden tidak datang ke BMT. Hal ini menunjukkan bahwa BMT memberikan kemudahan saat pengajuan pembiayaan. Pihak BMT menerapkan sistem "jemput bola" terhadap nasabahnya. Petugas BMT datang langsung ke tempat usaha nasabah untuk membantu proses pengajuan pembiayaan.

Proses pencairan membutuhkan waktu maksimal tiga hari. BMT mengharuskan nasabah untuk datang langsung ke kantor BMT untuk proses pencairan pembiayaan. Saat proses pencairan, pihak BMT dan nasabah menyepakati mengenai akad yang digunakan, sistem, dan tata cara pembayaran kembali pembiayaan. Dari hasil penelitian, terdapat 2 responden yang tidak datang ke BMT saat proses pencairan. Faktor kepercayaan responden terhadap petugas BMT menjadi alasan sehingga pencairan pembiayaan diantar oleh petugas.

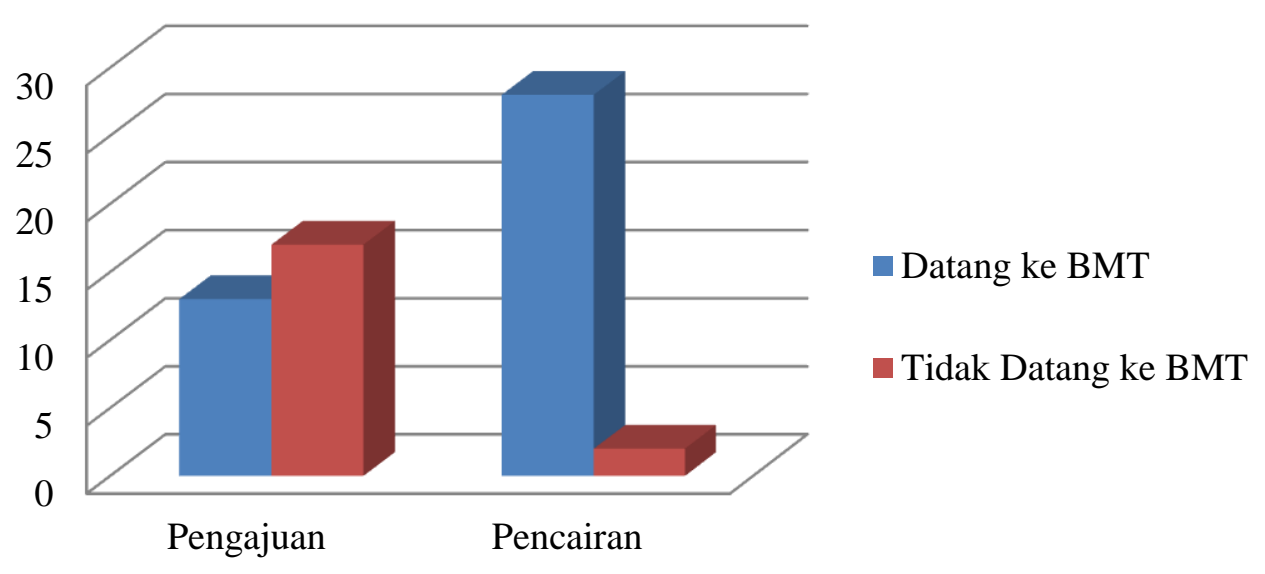

Gambar 1 Pengajuan dan pencairan pembiayaan

\begin{abstract}
Akad Pembiayaan
Gambar 2 menunjukkan bahwa akad pinjaman yang digunakan nasabah terhadap BMT didominasi oleh akad berbasis ijarah sebesar 73\%, sedangkan sisanya berbasis jual beli sebesar $27 \%$. Kenyataannya, tidak ada satu akad pun yang berbasis bagi hasil sebagai salah satu ciri khas pembiayaan syariah. Akad dengan basis ijarah dominan karena mayoritas responden merupakan pedagang pasar yang tidak memungkinkan untuk melakukan repayment pembiayaan ke kantor BMT, sehingga petugas BMT melakukan sistem "jemput bola" dengan konsekuensi peminjam memberikan ongkos jasa kepada petugas BMT.
\end{abstract}




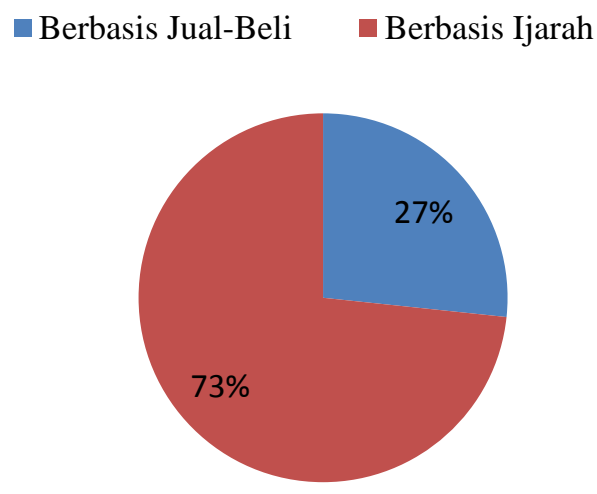

Gambar 2 Akad Pembiayaan Syariah

\section{Preferensi mengenai Pembiayaan Mikro Syariah BMT}

Masalah utama yang dihadapi oleh usaha mikro ialah keterbatasan modal untuk menjalankan dan mengembangkan usahanya. Pembiayaan mikro syariah dari BMT diberikan untuk membantu pelaku usaha mikro mengembangkan usahanya. Berdasarkan persepsi responden terhadap pembiayaan, proporsi responden sebesar $40 \%$ berpendapat bahwa pembiayaan yang diberikan menambah modal usaha. Proporsi responden yang berpendapat bahwa pembiayaan yang diberikan dapat meningkatkan omset usaha dan menambah kios ialah sebesar 30\% dan 6.67\%. Sementara itu, proporsi responden yang berpendapat bahwa pembiayaan yang diberikan tidak memberikan efek usaha karena adanya persaingan usaha ialah sebesar $6.67 \%$. Proporsi responden yang berpendapat bahwa pembiayaan yang diberikan hanya untuk menambah stok barang dan hanya memutar modal ialah sebesar 3.33\%. Proporsi responden yang berpendapat bahwa pembiayaan yang diberikan tidak memberikan efek pada usaha karena pembiayaan yang diberikan digunakan untuk konsumsi ialah sebesar $10 \%$.

Tabel 13 Preferensi responden mengenai pembiayaan

\begin{tabular}{lll}
\hline Berkembang atau Tidak & Alasan & Proporsi (\%) \\
\hline \multirow{2}{*}{ Usaha Berkembang } & Menambah modal usaha & 40.00 \\
& Meningkatkan omset dan keuntungan & 30.00 \\
& Menambah kios & 6.67 \\
\hline Total Usaha Berkembang & & 76.67 \\
\hline Usaha Tetap atau Tidak & Adanya persaingan usaha & 6.67 \\
Berkembang & Pembiayaan hanya menambah stok & 3.33 \\
\hline
\end{tabular}




\begin{tabular}{cl} 
barang & \\
Pembiayaan hanya memutar modal & 3.33 \\
Pembiayaan digunakan untuk konsumsi & 10.00 \\
\hline Total Usaha Tidak Berkembang atau Tetap & 23.33 \\
\hline
\end{tabular}

Sumber: Data primer, diolah (2014)

Dengan demikian, dapat disimpulkan bahwa pembiayaan yang diberikan oleh BMT dapat menjadikan usaha lebih berkembang dengan proporsi $76.67 \%$, sisanya sebesar $23.33 \%$ berpendapat bahwa pembiayaan yang diberikan tidak memberikan efek positif atau usaha cenderung tetap.

\section{Faktor-Faktor yang Memengaruhi Realisasi Pembiayaan}

Pembiayaan mikro syariah BMT merupakan salah satu bentuk penyaluran dana yang diberikan oleh BMT kepada nasabahnya yang bertujuan untuk menambah modal usaha. Dalam penelitian ini, data yang digunakan adalah data primer dari 30 responden yang merupakan anggota pembiayaan KJKS BMT UGT Sidogiri cabang Koja Jakarta. Analisis yang digunakan dalam penelitian ini ialah analisis regresi linier berganda.

Hasil akhir estimasi persamaan 1 dapat dilihat dalam Tabel 14. Variabel jangka waktu angsuran, aset usaha, frekuensi pembiayaan, dan dummy usaha signifikan pada taraf nyata. Uji asumsi klasik untuk metode regresi yaitu hasil uji normalitas, heteroskedastisitas, autokolerasi, dan multikolinieritas menunjukkan bahwa model sudah bersih dari masalah pelanggaran asumsi klasik.

Pada model estimasi yang layak (fit), residual model harus menyebar normal. Jika tidak menyebar normal, terdapat indikasi bahwa model bias sehingga asumsi klasik agar model tersebut menjadi BLUE tidak terpenuhi. Hasil Uji normalitas dilakukan dengan melihat nilai probabilitas Jarque-Bera (1.786570) lebih besar dari taraf nyata. Dengan demikian, model terbebas dari masalah normalitas.

Uji asumsi klasik untuk memeriksa ada atau tidaknya heteroskedastisitas pada model dilakukan dengan metode Breusch-Pagan-Godfrey Heteroskedasticity dan didapatkan nilai probabilitas dari obs*R-squared(0.2351) lebih besar dari taraf nyata. Artinya, model terbebas dari masalah heteroskedastisitas.

Uji asumsi klasik lainnya yang harus dipenuhi untuk mendapatkan model yang layak (fit) adalah uji ada atau tidaknya autokorelasi pada model. Uji autokorelasi dengan menggunakan metode Breusch-Godfrey Serial Correlation LM Test dan didapatkan nilai probabilitas dari obs*R-squared (0.1094) lebih besar dari taraf nyata. Hal ini menunjukkan bahwa model bebas dari masalah autokolerasi.

Uji asumsi klasik terakhir yang dilakukan ialah uji multikolinieritas dilakukan dengan correlation matrix, dimana batas terjadinya korelasi antara sesama variabel bebas adalah tidak lebih dari |0.80|. Dalam penelitian ini korelasi antar variabel dibawah $|0.80|$. Dengan demikian, dapat disimpulkan bahwa penelitian ini tidak mengandung gejala multikolinieritas sehingga dapat dilakukan analisis lebih lanjut karena model memenuhi asumsi BLUE (Blue Linier Unbiased Estimator).

Hasil estimasi model faktor-faktor yang memengaruhi realisasi pembiayaan KJKS BMT UGT Sidogiri cabang Koja Jakarta menunjukkan bahwa variabel yang berpengaruh ialah aset usaha, frekuensi pembiayaan, jangka waktu angsuran, dan dummy usaha. Hasil ini diperoleh dengan menggunakan metode OLS (Ordinary Least Square) dan diuji signifikansinya dengan menggunakan aplikasi software Eviews 6 . Hasil pengolahan data 
dengan metode OLS menunjukkan bahwa nilai R-Square dari persamaan adalah sebesar 67.18 artinya $67.18 \%$ keragaman faktor-faktor yang memengaruhi realisasi pembiayaan mikro syariah dapat dijelaskan oleh masing-masing variabel penjelas dalam model.Nilai probilitas F-statistik sebesar 0.000033 yang lebih kecil dari taraf nyata menunjukkan bahwa variabel-variabel independen berpengaruh nyata terhadap variabel dependen.

Variabel aset usaha berpengaruh positif dan signifikan pada taraf nyata $1 \%$. Hal ini sesuai dengan hipotesis penelitian. Koefisien variabel aset usaha sebesar 0.17 menunjukkan bahwa peningkatan aset usaha sebesar $1 \%$ akan meningkatan realisasi pembiayaan sebesar $0.17 \%$, ceteris paribus. Semakin besar aset usaha yang dimiliki pengusaha mikro, semakin besar realisasi pembiayaan yang diberikan oleh BMT.

Frekuensi pembiayaan berpengaruh positif dan signifikan pada taraf nyata $10 \%$. Hasil ini sesuai dengan hipotesis penelitian. Koefisien variabel frekuensi pembiayaan sebesar 0.26, artinya jika frekuensi pembiayaan meningkat $1 \%$, realisasi pembiyaan akan meningkat sebesar $0.26 \%$, ceteris paribus. Semakin tinggi intensitas pengambilan pembiayaan, semakin besar realisasi pembiayaan yang diberikan oleh BMT. Pihak BMT akan lebih mudah memberikan pembiayaan kepada nasabah yang sebelumnya sudah pernah melakukan pinjaman dibandingkan dengan nasabah baru. Hal ini dikarenakan informasi tentang nasabah dapat tersedia dengan mudah sehingga dapat menghilangkan masalah informasi tidak simetris (asymmetric information) yang merupakan masalah utama yang mempengaruhi kemungkinan terjadinya kegagalan pelunasan pembayaran kembali pembiayaan. Fenomena ini sejalan dengan Okurut et al. (2011) bahwa bank mempertimbangkan pengalaman kredit sebelumnya dalam pemberian kredit kepada UKM.

Jangka waktu angsuran berpengaruh positif dan signifikan pada taraf nyata $1 \%$. Hal ini sesuai dengan hipotesis penelitian. Koefisien variabel jangka waktu angsuran sebesar 0.35 menunjukkan bahwa peningkatan lama angsuran sebesar $1 \%$ akan meningkatkan realisasi pembiayaan sebesar $0.35 \%$, ceteris paribus. Jangka angsuran pembiayaan disepakati oleh kedua pihak, baik pihak BMT dan pengusaha mikro. Semakin lama jangka angsuran yang disepakati, semakin besar realisasi pembiayaan yang diberikan oleh BMT. Hal ini sebagai bentuk kehati-hatian pihak BMT untuk menghindari kredit macet.

Dummy usaha berpengaruh signifikan terhadap realisasi pembiayaan. Hasil ini sesuai dengan hipotesis penelitian. Jenis usaha perdagangan lebih tinggi mempengaruhi realisasi pembiayaan dibandingkan jenis usaha industri. Hal ini dikarenakan jenis usaha perdagangan membutuhkan modal yang lebih sedikit dibandingkan industri sehingga BMT dengan kapasitasnya sebagai lembaga keuangan mikro bisa menjangkau usaha mikro.

Laba usaha per bulan sebelum pembiayaan tidak berpengaruh nyata terhadap realisasi pembiayaan yang diberikan dengan nilai koefisien sebesar 0.05. Artinya, laba usaha tidak mempengaruhi realisasi pembiayaan yang diberikan oleh BMT. Hal ini tidak sesuai dengan hipotesis penelitian. KJKS BMT UGT Sidogiri cabang Koja Jakarta memiliki tujuan membantu pengusaha mikro yang mayoritas merupakan masyarakat kalangan menengah ke bawah yang mempunyai perolehan laba usaha relatif kecil. Penyaluran pembiayaan di BMT pada umumnya tidak hanya dilihat dari condition of economic seorang nasabah, tetapi juga dari faktor character dan lainnya yang menjadi pertimbangan. Oleh karena itu, laba usaha per bulan sebelum pembiayaan tidak berpengaruh nyata terhadap realisasi pembiayaan. Selain itu, indikasi lain mengapa laba usaha per bulan sebelum pembiayaan tidak berpengaruh terhadap realisasi pembiayaan adalah adanya pemberlakuan pemberian agunan/jaminan untuk kasus pembiayaan diatas Rp 3 juta. Agunan menjadi jaminan bagi BMT agar pembiayaan tetap dapat 
terealisasikan. Hal ini sejalan dengan penelitian Safitri (2007) yang menunjukkan bahwa laba usaha tidak signifikan mempengaruhi realisasi kredit yang diberikan. Hal ini disebabkan bank lebih melihat jumlah jaminan dalam pemberian kredit.

Tabel 14 Hasil estimasi faktor-faktor yang memengaruhi realisasi pembiayaan mikro syariah di KJKS BMT-UGT Sidogiri cabang Koja Jakarta

\begin{tabular}{llll}
\hline Variabel & Koefisien & t-Statistic & Probilitas \\
\hline Ln Aset Usaha & 0.172816 & 2.751621 & $0.0111^{*}$ \\
Ln Frekuensi Pembiayaan & 0.260616 & 1.965159 & $0.0611^{* * *}$ \\
Ln Jangka Waktu Angsuran & 0.350213 & 2.899318 & $0.0079^{*}$ \\
Dummy Usaha & 0.387079 & 1.932148 & $0.0652^{* * *}$ \\
Ln Laba Usaha & 0.054001 & 0.074135 & 0.4734 \\
C & 9.711161 & 7.910152 & 0.0000 \\
\hline R-squared & & & 0.671864 \\
\hline F-statistik & & 9.828061 \\
\hline Probabilitas F-Statistik & & 0.000033 \\
\hline Keterangan: *signifikan pada taraf nyata 1\% & \\
& $* *$ signifikan pada taraf nyata 5\% &
\end{tabular}

Hasil estimasi menunjukkan bahwa variabel aset usaha dan jangka waktu angsuran merupakan dua variabel paling responsif terhadap realisasi pembiayaan mikro syariah yang diberikan oleh KJKS BMT UGT Sidogiri cabang Koja Jakarta dengan tingkat signifikansi $1 \%$ dan nilai probabilitas 0.0079 serta 0.0111. Pihak BMT melihat aset usaha nasabah dalam memberikan realisasi pembiayaan dan menerapkan prinsip kehati-hatian dalam menentukan jangka waktu angsuran untuk menghindari kredit macet.

\section{Pengaruh Pembiayaan Mikro Syariah BMT terhadap Omset Usaha}

Pembiayaan mikro syariah yang diberikan BMT menjadi salah satu solusi keterbatasan permodalan bagi pengusaha mikro. Pembiayaan tersebut memberikan pengaruh positif terhadap usaha yang dilihat omset usaha setelah pembiayaan. Omset usaha setelah mendapatkan pembiayaan mikro syariah dapat dilihat dengan metode OLS (Ordinary Least Square) menggunakan aplikasi software Eviews 6.

Pelanggaran yang harus dihindari pada model agar model tersebut memenuhi syarat asumsi klasik dan dapat dikategorikan sebagai model yang BLUE (Best Linier Unbiased Estimator) adalah terhindardari masalah heteroskedastis. Hasil uji heteroskedastisitas dilakukan dengan menggunakan metode Breusch-Pagan Godfrey Heteroskedasticitydan didapatkan nilai probabilitas Obs*R-Squared (0.6261) lebih besar dari taraf nyata. Dapat disimpulkan tidak ada masalah heteroskedastisitas dalam model.

Uji asumsi klasik lainnya yang harus dipenuhi untuk mendapatkan model yang layak (fit) adalah uji normalitas dimana residual model harus menyebar normal. Jika residual tidak menyebar normal, dapat diindikasikan model menjadi tidak bias sehingga asumsi klasik agar model tersebut $B L U E$ tidak terpenuhi. Hasil estimasi uji asumsi menunjukkan bahwa nilai probabilitas Jarque Bera (0.516477) lebih besar dari taraf nyata. Artinya, model estimasi pengaruh pembiayaan mikro syariah BMT terhadap omset usaha memiliki residual yang menyebar normal, sehingga model estimasi tersebut termasuk model yang BLUE. 
Uji autokolerasi dibutuhkan untuk memenuhi persyaratan model yang layak (fit). Masalah autokolerasi dapat dilihat dengan menggunakan metode Breusch-Godfrey serial correlation LM test. Hasil estimasi menunjukkan bahwa nilai probabilitas Obs*RSquared (0.2773) lebih besar dari taraf nyata. Artinya, model terbebas dari masalah autokolerasi.

Pengujian terakhir untuk memenuhi kriteria BLUE ialah uji multikolinieritas. Uji multikolinieritas dilakukan dengan menggunakan correlation matrix dimana semua nilai korelasi antar variabel independen pada model kurang dari |0.8|. Pada model estimasi semua nilai kolerasi antar variabel independen kurang dari |0.8|. Artinya, tidak ada interaksi antar variabel independen pada model sehingga dapat disimpulkan model terbebas dari masalah multikolinieritas.

Hasil pengolahan data dengan metode OLS menunjukkan bahwa nilai R-Square dari persamaan sebesar 54.86 artinya $54.86 \%$ keragaman nilai omset usaha dapat dijelaskan oleh masing-masing variabel penjelas dalam model, sisanya dijelaskan oleh variabel lain. Nilai probilitas F-statistik sebesar 0.003077 yang lebih kecil dari taraf nyata menunjukkan bahwa variabel-variabel independen berpengaruh nyata terhadap variabel dependen.

Aset usaha berpengaruh positif terhadap omset usaha dengan koefisien 0.29 dan signifikan pada taraf nyata $(\alpha=5 \%)$. Hasil ini sesuai dengan hipotesis penelitian. Artinya, peningkatan aset usaha sebesar 1\% akan meningkatkan omset usaha sebesar $0.29 \%$ per bulan, ceteris paribus. Hal ini menunjukkan pengurangan atau penambahan aset usaha akan berpengaruh terhadap omset usaha.

Besarnya jumlah pembiayaan mikro syariah BMT berpengaruh negatif terhadap omset usaha dengan koefisien 0.93 dan signifikan pada taraf nyata $(\alpha=5 \%)$. Hasil ini tidak sesuai dengan hipotesis penelitian. Artinya, apabila besarnya jumlah pembiayaan meningkat $1 \%$, omset usaha akan menurun sebesar $0.93 \%$ per bulan, ceteris paribus.

Hal ini menunjukkan bahwa jumlah pembiayaan yang diberikan belum digunakan secara efektif oleh pelaku usaha mikro. Pengetahuan manajerial pelaku usaha mikro yang buruk mengakibatkan tidak adanya pengelolaan kas secara baik. Hal ini sejalan dengan penelitian Attom (2013) yang menunjukkan bahwa sebagian besar usaha mikro dan kecil di Ghana, umumnya tidak mengaplikasikan prosedur pengendalian kas secara benar; bahkan ketika sudah ada kontrol dan pengelolaan kas, mereka mengimplementasikan dengan buruk karena kelemahan dan kepuasan diri terhadap usaha tersebut.

Indikasi lain ialah jumlah pembiayaan yang diberikan BMT digunakan untuk kebutuhan konsumsi pengusaha mikro tidak untuk usaha produktif. Berdasarkan persepsi responden terhadap pembiayaan mikro syariah, sebesar $10 \%$ responden berpendapat bahwa pembiayaan mikro syariah yang diberikan tidak berdampak pada usaha karena pembiayaan digunakan untuk konsumsi. Hal ini menunjukan bahwa nasabah pembiayaan melakukan moral hazard. Moral hazard terjadi karena kurangnya pengawasan pihak BMT terhadap pengusaha mikro. Alokasi penggunaan pembiayaan lebih besar untuk kebutuhan konsumsi dibandingkan untuk modal mengembangkan usaha. Fenomena ini juga sejalan oleh penelitian Beik dan Purnamasari [4] menjelaskan bahwa jumlah pembiayaan yang diberikan oleh BMT berkolerasi negatif dan signifikan terhadap omset usaha setelah pembiayaan.

Lama pendidikan berpengaruh positif terhadap omset usaha dengan koefisien 1.42 dan signifikan pada taraf nyata $(\alpha=1 \%)$. Hasil ini sesuai dengan hipotesis penelitian. Artinya, peningkatan lama pendidikan sebesar $1 \%$ akan meningkatkan omset usaha sebesar $1.42 \%$, 
ceteris paribus. Semakin lama pendidikan pengusaha mikro, semakin besar kemungkinan omset usaha yang didapat.

Laba usaha mikro setelah pembiayaan berpengaruh positif terhadap omset usaha dengan koefisien 0.44 dan signifikan pada taraf nyata $(\alpha=5 \%)$. Hasil ini sesuai dengan hipotesis penelitian. Artinya, peningkatan (penurunan) laba usaha sebesar $1 \%$ akan meningkatkan (menurunkan) omset usaha sebesar $0.44 \%$ per bulan, ceteris paribus.

Lama usaha berpengaruh positif terhadap omset usaha dengan koefisien 0.48 dan signifikan pada taraf nyata $(\alpha=5 \%)$. Artinya, peningkatan lama usaha sebesar $1 \%$ akan meningkatkan omset usaha sebesar $0.48 \%$ per bulan, ceteris paribus. Lama usaha berhubungan dengan pengalaman pelaku usaha mikro. Responden dengan pengalaman usaha lebih lama memiliki omset usaha yang lebih besar. Semakin lama usaha yang dijalani oleh pengusaha mikro, semakin besar omset usaha yang didapat.

Dummy usaha memiliki pengaruh nyata terhadap omset usaha. Hasil ini sesuai dengan hipotesis penelitian. Jenis usaha perdagangan memiliki perputaran lebih tinggi dibandingkan jenis usaha industri, sehingga omset usaha lebih besar.

Tabel 15 Hasil estimasi faktor-faktor yang memengaruhi omset usaha

\begin{tabular}{|c|c|c|c|}
\hline Variabel & Koefisien & t-statistic & Probabilitas \\
\hline Ln Aset Usaha & 0.290899 & 1.875695 & $0.0734^{* * * *}$ \\
\hline Ln Jumlah Pembiayaan & -0.934202 & -2.449388 & $0.0223^{* *}$ \\
\hline Ln Lama Pendidikan & 1.423845 & 2.697228 & $0.0129^{*}$ \\
\hline Ln Laba Usaha & 0.446824 & 2.004450 & $0.0569^{* *}$ \\
\hline Ln Lama Usaha & 0.487201 & 2.493065 & $0.0203^{* *}$ \\
\hline Dummy usaha & 0.856163 & 1.928003 & $0.0663^{* * *}$ \\
\hline $\mathrm{C}$ & 14.78455 & 3.524659 & 0.0018 \\
\hline R-squared & & & 0.548689 \\
\hline F-statistik & & & 4.660431 \\
\hline Probabilitas F-statistik & & & 0.003077 \\
\hline $\begin{array}{l}* \text { signifi } \\
* * \text { signi } \\
* * * \text { sign }\end{array}$ & $\begin{array}{l}\text { taraf nya } \\
\text { a taraf ny } \\
\text { a taraf ny }\end{array}$ & & \\
\hline
\end{tabular}

Hasil estimasi menunjukkan bahwa lama pendidikan merupakan variabel yang paling responsif terhadap omset usaha nasabah setelah mendapatkan pembiayaan mikro syariah dengan nilai probabilitas sebesar 0.0129. Semakin lama pendidikan formal yang dijalani pengusaha mikro, semakin besar omset usaha yang didapatkan. Hal ini dikarenakan pendidikan memngaruhi kemampuan manajerial pemilik UMKM. 


\section{SIMPULAN DAN SARAN}

\section{Simpulan}

Berdasarkan penelitian yang telah dilakukan untuk menjawab rumusan masalah, dapat ditarik kesimpulan bahwa terdapat beberapa faktor yang memengaruhi realisasi pembiayaan yang diberikan oleh KJKS BMT UGT Sidogiri cabang Koja Jakarta. Aset usaha, frekuensi pembiayaan, dan jangka waktu angsuran berkolerasi positif terhadap realisasi pembiayaan, serta dummy usaha berpengaruh secara signifikan terhadap realisasi pembiayaan. Hal ini menunjukkan bahwa BMT tetap memperhatikan prinsip kehatihatian untuk mencegah kredit macet.

Faktor-faktor yang signifikan memengaruhi omset usaha ialah aset usaha, jumlah pembiayaan, laba usaha setelah pembiayaan, lama pendidikan, lama usaha, dan dummy usaha. Aset usaha, laba usaha setelah pembiayaan, lama pendidikan, dan lama usaha berkolerasi positif terhadap omset usaha setelah pembiayaan. Jumlah pembiayaan berkolerasi negatif terhadap omset usaha setelah pembiayaan. Dummy usaha juga berpengaruh secara signifikan terhadap omset usaha.

\section{Saran}

Hasil penelitian menunjukkan terdapat beberapa variabel yang memengaruhi realisasi pembiayaan mikro syariah dan dampaknya terhadap omset usaha. Terkait dengan hal tersebut saran dari hasil penelitian ini adalah sebagai berikut:

1. Pihak BMT dapat memberikan pembiayaan dengan jangka waktu yang lebih pendek untuk jumlah pembiayaan yang lebih kecil. Sebaliknya, jangka waktu panjang diberikan untuk pembiayaan yang relatif besar untuk mencegah kredit macet.

2. Kelemahan penelitian ini adalah tidak menggunakan variabel kontrol dan nasabah pembiayaan masih relatif baru, sehingga disarankan untuk penelitian selanjutnya untuk menggunakan variabel kontrol dan kriteria responden minimal sudah menjadi nasabah minimal 2 tahun, sehingga efek pembiayaan dapat lebih jelas dampaknya. 


\section{DAFTAR PUSTAKA}

Al-Arief, MNR. 2011. Dasar-dasar Ekonomi Islam. Jakarta(ID): PT Era Adicitra Intermedia.

Attom, BE. 2013. Cash Management Practices by Micro and Small-Scale Enterprises at Kasoa in The Central Region of Ghana.Asian Journal of Business and Management Sciences [internet]. [diunduh 2014 Juni 06]. Vol 3 No. 2 [01-12]. Tersedia pada: www.ajbms.org/articlepdf/1ajbms201303022754.pdf.

[BI] Bank Indonesia.2014. Statistik Ekonomi Keuangan Indonesia [internet]. [diunduh 06 Juni 2014]. Vol. XVI No 01. Tersedia pada: http://www.bi.go.id.

Beik IS, Purnamasari I. 2011. Empirical Role of Islamic Cooperatives in Financing Micro and Small Scale Entrepreneurs in Indonesia.Case study of KOSPIN Jasa Syariah Pekalongan.Di presentasikan pada Islamic Finance Conference.Qatar [internet]. [diunduh 2013 Oktober 27]. Tersedia pada: http://conference.qfis.edu.qa/app/media/223.

Gay LR, Mills GE, Airasian P. 2006. Educational Research: Competencies for Analysis and Applications $8^{\text {th }}$ Edition. New Jersey: Prentice Hall.

[KEMENKOP] Kementrian Koperasi dan UKM. 2014. Perkembangan Data Usaha Mikro, Kecil, dan Menengah (UMKM), dan Usaha Besar Tahun 2008-2012. [internet]. [diunduh 2014 Februari 13]. Tersedia pada: http://www.depkop.go.id.

Mahliza F. 2011. Analisis Faktor-Faktor yang Memengaruhi Realisasi Pembiayaan Murabahah untuk Usaha Mikro Agribisnis Sektor Perdagangan (Studi Kasus: KBMT Bil Barkah, Bogor) [skripsi]. Bogor (ID): Institut Pertanian Bogor

Okurut FN, Olalekan Y, Mangadi K. 2011. Credit Rationing and SME Development in Botswana: Implications for Economic Diversification [internet]. [diunduh 2014 Juli 08]. Tersedia pada: https://www.google.co.id/url?sa=t\&rct=j\&q=\&esrc=s\&source=web\&cd=2\&cad=rj a\&uact=8\&ved=0CC4QFjAB\&url=http $\% 3 \mathrm{~A} \% 2 \mathrm{~F} \% 2 \mathrm{Fwww}$. ajol.info\%2Findex.php \%2Fboje\%2Farticle\%2Fdownload\%2F72978\%2F61869\&ei=DMe9U_PRHISF8g W_ooG4CA\&usg=AFQjCNFieIXhpGCmijfvxa8M_ynPE0ULEw\&sig2=KyvCD4 9xe9XtaxenAolL1A\&bvm=bv.70138588,d.dGc.

Safitri I. 2007. Analisis Faktor-faktor yang Memengaruhi Volume Penyaluran Kredit Mikro, Kecil dan Menengah (MKM) di Indonesia [skripsi]. Bogor(ID): Institut Pertanian Bogor

Septiana RM. 2013.Analisis Dampak Pembiayaan Mikro Syariah Terhadap Perkembangan Keuntungan UMKM di Kabupaten Bogor [skripsi]. Bogor (ID): Institut Pertanian Bogor

Setyobudi A. 2007. Peran Serta Bank Indonesia dalam Pengembangan Usaha Mikro, Kecil, dan Menengah.Buletin Hukum Perbankan dan Kebanksentralan 29. Volume 5. No 2. Agustus 2007. 